\title{
Representasi Sejarah dan Dampak Perang Dunia II dalam Komik Kono Sekai No Katasumi Ni Karya Fumiyo Kouno
}

\author{
Historical Representations and the Impacts of World War II in Comic "Kono Sekai No \\ Katasumi Ni" by Fumiyo Kouno
}

\author{
Reza Taufan Adhitya ${ }^{1, *}$, Renny Anggraeny ${ }^{2}$, dan Ida Ayu Laksmita Sari ${ }^{3}$ \\ ${ }^{1,2,3}$ Program Studi Sastra Jepang, Fakultas Ilmu Budaya, Universitas Udayana \\ Jalan Pulau Nias No. 13, Kota Denpasar, Bali 80113 \\ 1, ${ }^{*}$ Corresponding email: rezataufanadhitya@gmail.com \\ ${ }^{2}$ Email: renny_anggraeny@unud.ac.id \\ ${ }^{3}$ Email: dayumita23@gmail.com
}

Received: 20 January 2021 Accepted: 19 April 2021 Published: 1 June 2021

\begin{abstract}
This study aims to find out and understand the representation of the history of World War II and the impact of World War II on the Japanese, especially the people who live in Kure in the comic Kono Sekai no Katasumi ni by Fumiyo Kouno. The method used in this study is the descriptive analysis method. The theory used in this study is the theory of New Historicism by Stephen Greenbalt. The results show, there are five historical facts, the establishment of tonarigumi, the creation of the tatemono sokai policy, the air attack on Kure, the attack on the Hiro Naval Base, and the dropping of Atomic Bomb on Hiroshima, which also affected Kure area which is 20 kilometres to southeast Hiroshima. In addition, as a result of the occurrence of World War II, the mindset of the Japanese people regarding war changed from those previously zealous in warfare to preferring to maintain peace. On the other hand, the impact of World War II is still being felt today by the Japanese people, especially for victims who survived and were still alive until the time this comic was published.

Keywords: world war II, Kure, new historicism
\end{abstract}

\begin{abstract}
Abstrak: Penelitian ini bertujuan mengetahui dan memahami representasi sejarah Perang Dunia II dan dampak Perang Dunia II bagi bangsa Jepang khususnya masyarakat yang tinggal di Kure dalam komik Kono Sekai no Katasumi ni karya Fumiyo Kouno. Metode yang digunakan adalah metode deskriptif analisis. Teori yang digunakan adalah teori New Historicism dari Stephen Greenbalt. Hasil penelitian menunjukkan bahwa terdapat lima fakta sejarah, yakni dibentukkan organisasi tonarigumi, dibuatnya kebijakan tatemono sokai, serangan udara di Kure, serangan terhadap Pangkalan Angkatan Laut Hiro, dan juga dijatuhkannya Bom Atom di Hiroshima yang berdampak juga di daerah Kure yang berjarak 20 kilometer ke tenggara Hiroshima. Selain itu, diketahui bahwa akibat dari terjadinya Perang Dunia II pola pikir dari bangsa Jepang terkait peperangan berubah dari yang sebelumnya bersemangat dalam peperangan menjadi lebih memilih untuk mempertahankan kedamaian. Di sisi lain dampak dari Perang Dunia II juga masih dirasakan hingga saat ini oleh bangsa Jepang khususnya bagi korban-korban yang selamat dan masih hidup hingga saat komik ini diterbitkan.

Kata kunci: perang dunia II, Kure, new historicism
\end{abstract}

To cite this article:

Adhitya, R. T., Anggraeny, R., \& Sari, I. A. L. (2021). Representasi Sejarah dan Dampak Perang Dunia II dalam Komik Kono Sekai No Katasumi Ni Karya Fumiyo Kouno. Diglosia: Jurnal Kajian Bahasa, Sastra, dan Pengajarannya, 4(2), 189-204. https://doi.org/10.30872/diglosia.v4i2.178 


\section{A. PENDAHULUAN}

Akhir abad ke-19, setelah kekuasaan kaisar Meiji berakhir, perekonomian serta kemiliteran Jepang berkembang pesat hingga diakui oleh negara-negara adidaya pada masa itu. Perkembangan Jepang pada masa itu mendorong Jepang untuk ikut serta dalam beberapa peperangan, bahkan Jepang adalah salah satu negara yang menjadi pemicu terjadinya perang. Awal abad ke-20, Jepang memulai peperangan dengan Cina dan Korea serta pada saat yang bersamaan negara-negara bagian barat juga sedang bergejolak. Setelah peperangan dengan Cina, tepatnya pada tanggal 8 Desember 1941 Jepang membombardir Pearl Harbor yakni pangkalan militer Amerika yang berbasis di Hawai (Carter, 1991, p. 4). Penyerangan ini yang membawa Jepang terlibat dalam perang dunia ke-2.

Ikut sertanya Jepang dalam perang dunia ke-2 melawan Amerika Serikat mengakibatkan perekonomian Jepang mulai melemah. Ini juga mengakibatkan masyarakat Jepang kekurangan pasokan makanan khususnya wilayah-wilayah yang menjadi kawasan peperangan. Kisah sejarah mengenai peristiwa-peristiwa pada masa peperangan ini banyak dikisahkan dalam berbagai karya sastra, seperti novel, drama, dan juga komik. Salah seorang komikus yang bernama Fumiyo Kouno mengangkat kisah perang dunia ke-2 ke dalam komik yang berjudul Kono Sekai no Katasumi ni. Komik ini bercerita tentang kisah seorang gadis yang tinggal di Hiroshima bernama Suzu. Suzu menikah pada umur 18 tahun dengan seorang pria bernama Shusaku, pria yang ia temui 10 tahun yang lalu. Shusaku tinggal di Kure. Kure adalah salah satu kota yang berada di Prefektur Hiroshima yang berjarak sektitar 20 kilometer tenggara Hiroshima. Shusaku adalah seorang petugas pengadilan di pengadilan militer Jepang di Kure. Suzu pindah dari Hiroshima setelah menikah, lalu tinggal bersama keluarga Shusaku di Kure. Suzu pindah ke Kure pada saat peperangan Jepang melawan Amerika Serikat semakin memanas. Suzu menyaksikan hal-hal yang sangat mengerikan seperti serangan-serangan udara dari angkatan udara Amerika hingga bom atom yang dijatuhkan oleh Amerika di Hiroshima yang megakibatkan Suzu berpisah dari keluarganya.

Komik Kono Sekai no Katasumi ni sebagai salah satu karya sastra yang merupakan karya fiksi namun sekaligus mengandung kejadian-kejadian sejarah didalamnya. Peristiwa fiksi dalam komik ini adalah karakter-karakter dalam komik yang diciptakan oleh pengarang, namun masih merupakan gambaran masyarakat pada masa itu. Komik ini menggambarkan peristiwa sejarah yang terjadi pada masa perang dunia ke-2. Salah satu peristiwa sejarah yang digambarkan pada komik ini adalah dijatuhkannya bom atom di Hiroshima. Peristiwa nyata pada tahun 1945 pada tanggal 6 Agustus yaitu penjatuhan bom atom yang disebut oleh Amerika bernama Little Boy di kota Hiroshima (Tibbets, 2014). Selain peristiwa tersebut, terjadi beberapa peristiwa sejarah yang digambarkan dalam komik Kono sekai no Katasumi ni karya Fumiyo Kouno.

Penelitian mengenai fakta sejarah dalam perang dunia II juga pernah dilakukan oleh Malino (2013). Malino mengkaji fakta sejarah dalam novel Mawar Jepang karya Rei Kimura. Namun, penelitian Malino lebih menunjukkan fakta sejarah secara umum yang terjadi di Jepang, yakni semangat nasionalisme rakyat Jepang, wajib militer untuk pemuda Jepang, hingga serangan udara kamikaze dalam melawan amerika menjelang akhir perang, serta kekalahan Jepang yang menandai perang asia pasifik (Malino, 2013, berikan halaman di bagian simpulan penelitian malino ini). 
Sedangkan dalam penelitian ini dikaji secara khusus kota Kure di daerah tenggara prefektur Hiroshima yang terdampak Perang Dunia II.

Komik Kono Sekai no Katasumi ni karya Fumiyo Kouno dikategorikan sebagai karya sastra fiksi sejarah. Menurut Abrams (1999, p. 94-95), istilah fiksi sebagai karya naratif yang isinya bukanlah hal yang sepenuhnya berisi kepalsuan namun berdasar pada kebenaran sejarah yang benar ada dan terjadi di dunia nyata sehingga kebenarannya pun dapat dibuktikan dengan data empiris. Pernyataan tersebut adalah alasan dalam pemilihan representasi sejarah dalam Komik Kono Sekai no Katasumi ni sebagai objek kajian dan penelitian. Komik Kono Sekai no Katasumi ni yang menonjolkan peristiwa sejarah yang terjadi di Kure pada masa perang dunia ke-2 yang tak luput dari imajinasi pengarang yang mengutamakan reaksi pembaca sebagai penikmat karyanya.

\section{B. METODE}

Objek penelitian yang digunakan berupa komik Kono Sekai no Katasumi ni karya Fumiyo Kouno (2007-2009). Data dikumpulkan dengan menggunakan metode studi pustaka oleh Sugiyono (2004) dan metode simak oleh Sudaryanto (2003). Setelah data terkumpul, dirumuskan dua rumusan masalah yang akan dibahas dalam penelitian ini, yaitu representasi sejarah perang dunia ke-2 dalam komik Kono Sekai no Katasumi ni karya Fumiyo Kouno dan peristiwa sejarah apa saja yang ditampilkan dalam komik Kono Sekai no Katasumi ni. Teori yang akan digunakan untuk membedah data adalah teori New Historicism oleh Stephen Greenbalt (William, 2003, p. 118) untuk membandingkan unsur sejarah yang terdapat dalam karya sastra dengan fakta sejarah. Analisis data juga dibantu dengan menggunakan metode deskriptif analisis (Ratna, 2004). Setelah menemukan hasil, hasil analisis kemudian disimpulkan dan disajikan menggunakan metode informal dan teknik narasi.

\section{PEMBAHASAN}

Pada penelitian ini dipaparkan mengenai representasi atau penggambaran perang dunia ke-2 dan dampak perang yang terdapat dalam komik Kono Sekai no Katasumi ni karya Fumiyo Kouno.

\section{Penggambaran Perang Dunia ke-2 pada Komik Kono Sekai no Katasumi ini}

Komik ini memiliki latar waktu pada saat perang dunia ke-2 tepatnya pada zaman shouwa atau pada tahun 1941 hingga 1945 masehi, dan komik ini berfokus pada penggamabaran perang di kota kure, prefecture Hiroshima, bagian selatan Jepang. Pada penelitian ini tidak hanya

\section{a. Serangan Udara di Kure}

Serangan udara oleh sekutu di Jepang sudah dimulai dari akhir tahun 1944 yakni bulan November dengan wilayah yang diserang adalah ibukota Jepang, Tokyo. Serangan-serangan udara oleh sekutu mulai gencar diterima Jepang di daerah-daerah perkotaan dan industri-industri penting bagi pemerintahan Jepang di bagian selatan kepulauan Jepang hingga pada wilayah-wilayah sekitar prefektur Hiroshima, salah satu kota yang yang ditargetkan sekutu adalah kota Kure yang berada di bagian barat daya (Craven dan Kate, 1953, p. 558).

Awal tahun 1945 serangan udara membombardir Kure, salah satu serangan terjadi pada tanggal 19 Maret 1945. Pengemboman ini dilakukan oleh Satuan Tugas Angkatan Laut Amerika Serikat 58, yang ditargetkan kepada kapal perang milik Jepang yang berlabuh di Markas Pangkalan Angkatan Laut Hiro di Kure dan 
sekitarnya. Serangan ini belum dapat menenggelamkan kapal-kapal milik Jepang, namun kapal induk pengawal dan kapal penjelajah rusak parah (Tillman, 2010, p. 128). Penggambaran serangan ini terdapat dalam komik yang ditunjukkan oleh Gambar 1.

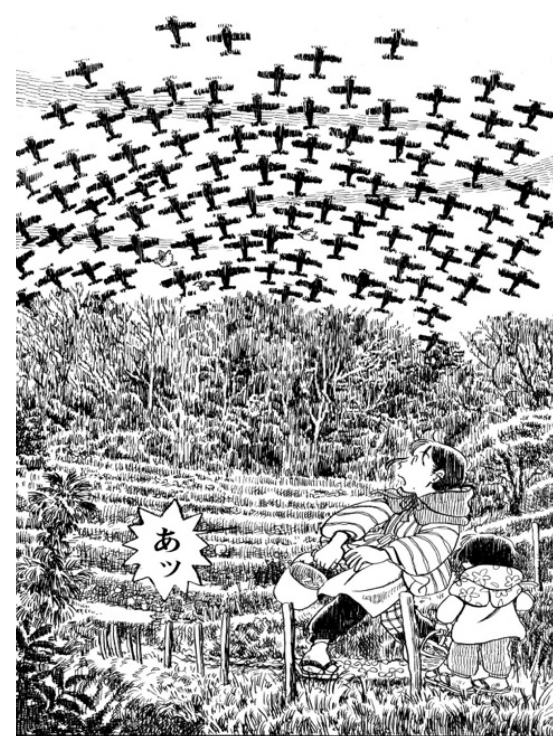

Gambar 1. Serangan udara di Kure

(Kono Sekai no Katasumi ni dai 26 kai, 2011, p. 50)

Pada Gambar 1 digambarkan ratusan pesawat memenuhi langit Kure dengan tujuan untuk membombardir Markas Pangkalan Laut Kure. Dalam komik berlatarkan waktu pada pagi hari, ketika pemeran utama yakni Suzu dan adik iparnya Hiromi baru saja keluar rumah untuk berkebun di perkebunan milik keluarganya. Seketika tiba-tiba pesawat-pesawat pengeboman Amerika Serikat memenuhi langit Jepang disertai dengan suara alarm yang berbunyi. Peristiwa sejarah yang sebenarnya serangan ini berlatar waktu yang sama dengan yang digambarkan dalam komik, yakni pada waktu pagi hari sekitar jam 7 pagi waktu setempat hingga jam 11 pagi setempat, pengemboman terjadi tanpa henti.

Dokumen-dokumen sejarah menjelaskan bahwa sebelum serangan yang terjadi di Kure pada tanggal 19 Maret 1945, Satuan Tugas Angkatan Laut Amerika Serikat 58 memulai serangan udara dengan target serangan yakni 45 lapangan terbang yang berada di Kyushu. Keesokan harinya Satuan Tugas Angkatan Laut Amerika Serikat 58 memulai serangannya ke wilayah Kure dengan target serangan adalah Markas Pangkalan Angkatan Laut Hiro. Pesawat tempur yang digunakan dalam serangan ini adalah pesawat tempur Grumman F6F Hellcats. Dalam serangan ini tercatat sebanyak 14 pesawat tempur Amerika dan 25 pesawat tempur Jepang tumbang (Tillman, 2010, p. 128). Kejadian-kejadian yang menyeramkan ini dapat dirasakan oleh pembaca dalam komik Kono Sekai no Katasumi ni, khusunya serangan-serangan yang terjadi di wilayah Kure.

\section{b. Serangan terhadap Pangkalan Angkatan Laut di Hiro}

Salah satu sasaran serangan Amerika Serikat adalah Pangkalan Angkatan Laut Hiro yang berada di Kure, bagian barat daya prefektur Hiroshima. Bukan hanya 
tempat singgahnya kapal-kapal perang milik Jepang namun Pangkalan Angkatan Laut Hiro juga salah satu fasilitator dalam memproduksi pesawat amfibi, kapal terbang, dan mesin aero untuk Angkatan Laut Kekaisaran Jepang sebelum dan selama Perang Dunia II (Johnson, 2006, p. 17). Serangan terhadap Pangkalan Angakatan Laut Hiro menyebabkan kerusakan parah terhadap Pangkalan Angkatan Laut Hiro dan juga terhadap pabrik pesawat terbang yang berada tepat di wilayah Pangkalan Angkatan Laut Hiro berada. Serangan ini digambarkan dalam komik dalam Data 1.

(1) (ラジオ) 広工廠及び十一航空廠の工場の一部に被害あれど人員の死傷は きわめて軽微...

$$
\text { (この世界の片隅に 第 } 30 \text { 回, 2011, p. 83) }
$$

(Rajio) Hiro koushou oyobi Junichi koukuushou No koujou no ichibu ni higaiare do jin'in no shishou wa kiwamete keibi...

(Kono Sekai no Katasumi ni dai 30 kai, 2011, p. 83)

(Radio) meskipun beberapa bagian dari Hiro Arsenal dan pabrik pesawat rusak, korbannya sangat ringan...

(Kono Sekai no Katasumi ni dai 30 kai, 2011, p. 83)

Dalam Data 1 dijelaskan pada bab 30 komik dengan latar waktu tahun ke-20 bulan ke-5 (tahun Showa) yang pada kalender masehi adalah bulan Mei 1945. Radio setempat menyiarkan informasi bahwa serangan yang terjadi pada pagi hari waktu setempat telah mengakibatkan kerusakan yang parah terhadap Pangkalan Angkatan Laut Hiro namun dengan korban yang minim. Salah satu keluarga Suzu yakni Entarou, ayah dari suami Suzu juga menjadi korban luka ringan dari serangan ini.

Menurut sejarah, serangan ini terjadi pada tanggal 5 Mei 1945 dan menyebabkan kiranya sekitar 1000 lebih korban dengan 22 pekerja angkatan laut (bukan prajurit) dan 32 warga sipil dilaporkan meninggal atau menghilang dalam serangan ini (Craven dan Kate, 1953, p. 649). Dalam serangan ini, Amerika Serikat mengerahkan 148 pesawat tempur B-29 superfortresses. B-29 juga meleteakkan ranjau laut di sekitar perairan Kure yang bertujuan dengan menenggelamkan kapal-kapal perang milik Jepang (Craven dan Kate, 1953, p. 649).

\section{c. Dijatuhkan Bom Atom di Hiroshima}

Pada puncak Perang Dunia II berlangsung, Amerika Serikat menjatuhkan bom atom di dua kota besar Jepang, yakni Hiroshima dan Nagasaki pada tanggal 6 dan 9 Agustus 1945. Amerika Serikat dalam pengeboman ini telah disetujui oleh Britinia Raya seperti yang terurai dalam Quebec Agreement. Kedua bom yang telah menewaskan sekitar 130 ribu korban jiwa ini menjadi satu-satunya penggunaan senjata nuklir yang terjadi sepanjang sejarah peperangan hingga saat ini (Thomas dan Morgan, 1977, p. 414). Kejadian ini ditunjukkan dalam komik dengan data 2 berikut. 
(2)

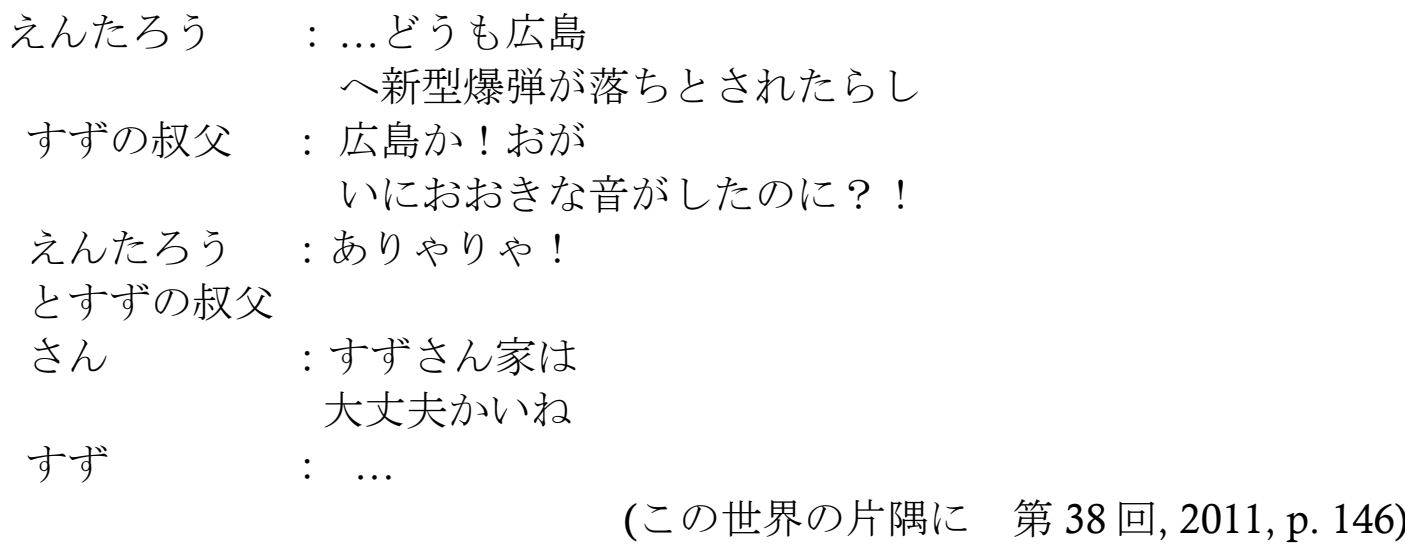

$\begin{array}{ll}\text { Entarou } & \text { :...doumo Hiroshima e shingata bakudan ga ochi to saretarashi } \\ \text { Suzu no oji } & \text { : Hiroshima ka! Ogaini ookina oto ga shitanoni?! } \\ \text { Entaraou } & \text { : Aryarya! } \\ \text { Suzu no oji } & \\ \text { San } & \text { : Suzusangata wa daijoubukaine } \\ \text { Suzu } & \text { :... }\end{array}$

(Kono Sekai no Katasumi ni dai 38 kai, 2011, p. 146)
Entarou $\quad$ : Kelihatannya, itu adalah bom baru yang dijatuhkan di Hiroshima
Paman Suzu : Hiroshima! Walaupun kita mendengarnya begitu keras dan jelas di sini?!
Entarou dan : Astaga!
Paman Suzu
San
: Semoga keluargamu baik-baik saja, Suzu-san.
Suzu

(Kono Sekai no Katasumi ni dai 38 kai, 2011, p. 146)

Dalam Data 2 terjadi saat makan malam di kediaman keluarga Shusaku. Entarou dan Paman Suzu memulai pembicaran tentang yang terjadi pagi hari itu bahwa terdapat kilatan cahaya disertai dengan getaran seperti gempa dan juga suara yang menggelegar diikuti dengan awan yang menjulang tebal kelangit. Kejadian itu sepertinya telah diketahui bahwa itu terjadi di Hiroshima tempat asal Suzu, sehingga mereka berdua tersadar hal itu tak baik untuk didengarkan oleh Suzu. Kejadian yang terjadi tersebut tidak pernah terjadi sebelum selama peperangan, orang-orang mulai berpikir jika itu terjadi di Hiroshima maka itu adalah sesuatu yang besar telah terjadi di Hiroshima karena jarak dari Hiroshima menuju Kure terbilang lumayan jauh. Namun suara dentuman keras dan juga awan yang menjulang tebal ke langit dapat terlihat dan dirasakan oleh masyarakat Kure.

Dalam data sejarah, Hiroshima adalah target utama dalam misi pengeboman pada 6 Agustus 1945, dengan Kokura dan Nagasaki menjadi target alternatif. Pesawat pembawa bom ini berasal dari skuadron pengeboman B-29 bernama Enola Gay, dengan Kolonel Paul W. Tibbets sebagai pilot. Pesawat ini ditemani oleh dua pesawat lainnya yakni The Great Artiste sebagai pesawat pendukung dan pembawa peralatan, dengan Mayor Charles W. Sweeney sebagai pilot, dan satu pesawat yang bertugas untuk memotret serangan tersebut yakni pesawat bernama Necessary Evil, 
dengan Kapten George W. Marquardt sebagai pilot. Ketiga pesawat ini berangkat dari Tinian dengan jarak tempuh menuju Hiroshima sekitar 6 jam penerbangan (The Atomic Heritage Foundation, 2007).

\section{d. Tonarigumi}

Tonarigumi adalah sebuah struktur kemasyarakatan yang sudah ada sejak sebelum zaman $E d o$ atau yang juga disebut kerukunan tetangga namun hanya struktur kemasyrakatan ini hanya berada pada kebudayaan masyarakat Jepang tanpa ada struktur yang jelas dari pemerintahan Jepang sehingga sistem ini diresmikan pada tanggal 11 September 1940 di bawah kabinet perdana menteri Fumimaro Konoe dikarenakan struktur kemasyarakatan ini pada masa peperangan terjadi dirasa sangat penting untuk mengorganisir masyarakat dalam membantu kemaslahatan perang (Pekkanen, 2006, p. 104). Asosiasi ini dibentuk oleh pemerintahan Jepang dan dianggap penting untuk menunjang keberhasilan Jepang dalam perang-perang yang sedang berlangsung pada masa era perang dunia ke- 2 . Setiap keluarga diwajibkan untuk terlibat dalam kegiatan ini dan di bagi menjadi unit untuk mengalokasikan barang-barang yang telah dijatahkan pemerintah Jepang serta mendistribusikan kebutuhan kepemerintahan ke seluruh wilayah kekuasaan Jepang. Selain itu, terdapat unit yang bertanggung jawab dalam pemadaman kebakaran, kesehatan, dan pertahanan sipil. Salah satu unit yang bertanggung jawab untuk mendistribusikan bahan-bahan makanan digambarkan dalam komik dengan salah satu lagu yang berjudul "Tonarigumi" karya Okamoto Ippei dalam komik ditunjukkan pada Data 3.

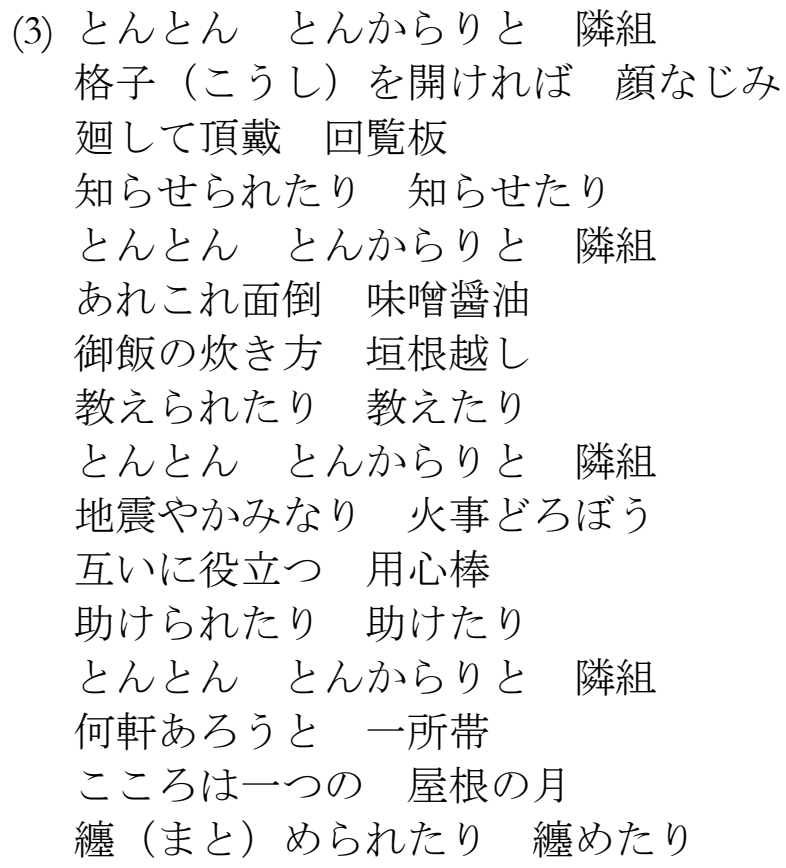

ton ton ton karari to tonarigumi

kōshi (ko ushi) o akereba kaonajimi

mawashite chōdai kairan-ban

shirase rare tari shirase tari 


\begin{abstract}
ton ton ton karari to tonarigumi
arekore mendō miso shōyu

gohan no taki-kata kakinegoshi

oshie rare tari oshie tari

ton ton ton karari to tonarigumi

jishin ya kami nari kaji doro bō

tagai ni yakudatsu yōjinbō

tasuke rare tari tasuke tari

ton ton ton karari to tonarigumi

nan-ken arou to hitoshotai

kokoro wa hitotsu no yane no tsuki

matoi (mato) me rare tari matome tari
\end{abstract}

(Kono Sekai no Katasumi ni Dai 4 kai, 2011, p. 84)

Tum tum tum tum rukun tetangga.

Buka gerbangmu dan ada wajah yang akrab.

Tolong sampaikan padaku surat edaran kota.

Sampaikanlah, hingga semua orang tahu.

Tum tum tum tum rukun tetangga.

Tugas ini dan itu, membagikan miso dan kecap.

Mengobrol di seberang pagar, berbagi tip memasak.

Ajarkan satu kepadaku dan aku akan ajarkan satu kepadamu.

Tum tum tum tum rukun tetangga.

Gempa bumi. Petir. Kebakaran. Pencuri.

Kita adalah pembela terbaik satu sama lain.

Kamu membantuku dan Aku akan membantumu.

Tum tum tum tum rukun tetangga.

Kita tinggal di banyak rumah, tetapi kita adalah satu keluarga besar.

Hati kita satu, bersinar seperti bulan.

Kita datang bersama, kita semua berkumpul bersama.

(Kono Sekai no Katasumi ni dai 4 kai, 2011, p. 84)

Lagu tonarigumi ini diciptakan oleh Ippei Okamoto dan disiarkan melalui radio dan televisi pada tahun 1940 yang dibawakan oleh Nobuo Iida. Lagu tersebut menggambarkan kegiatan yang dilakukan oleh masyarakat yang berada dalam lingkup rukun tetangga pada masa Perang Dunia II seperti dilakukan pertemuan rutin di setiap rukun tetangga untuk membahas pekerjaan-pekerjaan yang perlu dilakukan bersama, contohnya membagikan subsidi bahan makanan, saling bertukar keterampilan, melakukan kerja bakti, memeberikan informasi terkait hal-hal yang perlu diperhatikan dalam peperangan sebagai waga sipil.

Dalam Data 3 juga menggambarkan inti dari dibentuknya tonarigumi yakni pada bait terakhir, "tasuke rare tari tasuke tari ton ton ton karari to tonarigumi nan-ken arou to hitoshotai" "kamu membantuku dan aku akan membantumu. Tum tum tum tum tonarigumi. Kita tinggal di banyak rumah, tetapi kita adalah satu keluarga besar' di bait ini dijelaskan bahwa dibentuknya tonarigumi bertujuan untuk mengorganisasikan bala bantuan kepada sesama masyarakat serta untuk menyatukan rasa kekeluargaan masyarakat Jepang pada masa Perang Dunia II. 
Sesuai dengan teori new historicism, bahwa kajian sastra tidak dapat dilepaskan dari praksis-praksis social disekelilingnya. Dalam dokumen sejarah tertulis bahwa anggota-anggota organisasi tonarigumi diharapkan dapat mengawasi satu sama lain demi menghindari pengintaian terhadap tentara Jepang dan juga untuk menghindari kegiatan yang berbau anti Jepang. Para anggota juga memiliki tanggung jawab untuk mengatur jalannya pendistribusian makanan pada masa perang dunia berlangsung (Pekkanen dan Read, 2009, p. 61). Dengan demikian dalam komik disisipkan kehidupan sosial sehari-hari masyarakat Jepang pada masa Perang Dunia II yang digambarkan melalui program tonarigumi.

\section{e. Tatemono Sokai}

Tatemono sokai, disebut juga dengan penggusuran bangunan yang merupakan program yang diresmikan pemerintah Jepang saat Perang Dunia II berlangsung. Tujuannya ialah untuk mengurangi dampak kebakaran yang luas dari serangan udara yang diluncurkan Amerika Serikat serta mengamankan bangunan-bangunan yang penting untuk kepemerintahan Jepang. Tatemono sokai ini dimulai pada bulan November 1944 di wilayah Hiroshima. Program Tatemono Sokai diberlakukan di seluruh wialayah Jepang, termasuk di wilayah Kure (Akira, 1991,p. 102).

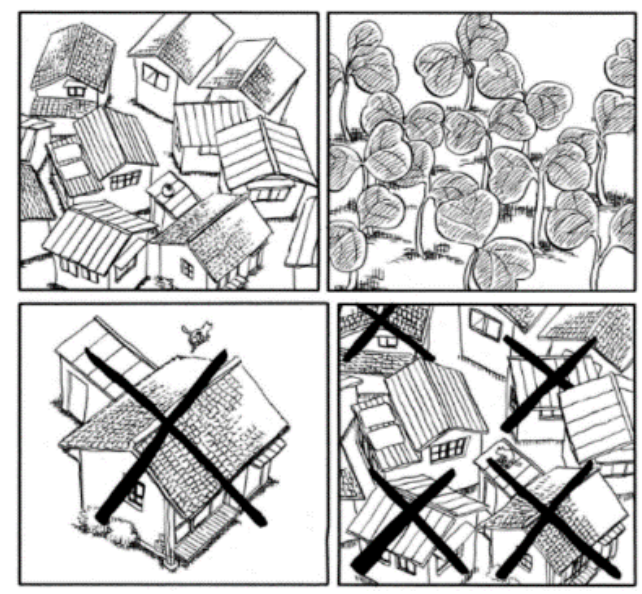

\section{Gambar 2. Tatemono sokai}

(Kono Sekai no Katasumi ni dai 10 kai, 2011, p. 136)

Pada Gambar 2, penulis menggambarkan peristiwa tatemono sokai ini dengan gambaran ketika karakter utama Suzu sedang bercocok tanam sayur komatsuna atau bayam mustard Jepang di kebunnya dan memperhatikan bibit tanamannya yang tumbuh tak beraturan. Ia berpikir tanaman sayur komatsuna-nya seharusnya diatur agar terlihat lebih rapi. Di sini penulis merepresentasikan sayur komatsuna sebagai rumah-rumah yang dibangun tak beraturan sejak bertahun-tahun dan seharusnya ditata kembali agar menjadi lebih teratur dan tertata dengan baik.

Pemerintah Jepang mewajibkan seluruh masyarakat Jepang untuk membantu pemerintah selama peperangan. Salah satu program pemerintah yang ditugaskan kepada masyarakat adalah sebagai pekerja dalam program tatemono sokai pada perang dunia ke-2 yang hingga saat ini disebut sebagai Tatemono Sokai Doin Gakuto no Genbaku Hisai wo Kirokusuru Kai (Sebuah kelompok pelajar yang dimobilisasi 
untuk bekerja merobohkan rumah-rumah dan menjadi korban bom atom) (Mizukawa, 2020). Pemerintah melakukan program ini karena bangunan-bangunan rumah di Jepang pada masa perang tersebut terbuat dari kayu sehingga mudah terbakar. Sekitar 610.000 rumah telah dirobohkan secara nasional. Dalam banyak kasus, tanah dari bangunan yang telah dirobohkan menjadi jalan raya setelah perang (Kawaguchi, 2011, p. 1509).

Dalam program tatemono sokai, pemerintah mengerahkan tenaga masyarakat untuk terlibat dalam pembongkaran bangunan-bangunan yang dinilai tidak pada tempatnya, masyarakat yang dilibatkan adalah kalangan orang dewasa dan siswasiswa menengah pertama. Pada tanggal 6 Agustus 1945, murid-murid yang dimobilisasi untuk melakukan program ini terkena serangan bom atom yang terjadi di Hiroshima. Korban-korban yang terkena serangan bom atom masih tidak diketahui secara pasti jumlahnya, tetapi diperkirakan sekitar 6.000 korban jiwa menurut Museum Bom Atom di Kota Hisorhima (Hayakawa, 2015, p. 7).

\section{Dampak Dari Perang Dunia II dalam Komik Kono Sekai no Katasumi ni a. Berkurangnya Bahan Makanan}

Bahan makanan adalah hal yang sangat berharga dan sangat dibutuhkan pada saat peperangan terjadi. Di dalam komik Kono Sekai no Katasumi ni digambarkan mengenai kekurangan bahan makanan yang terjadi di Jepang. Pada saat peperangan berlangsung, bahan-bahan makanan akan didistribusikan oleh pemerintah melalui unit pendistribusian dalam tonarigumi. Bahan makanan yang didistribusikan sering kali tak mencukupi untuk seluruh masyarakat, dan juga distribusi pasokan bahan makanan ini bukan serta merta diberikan secara gratis namun harus membayar. Pendistribusian pasokan bahan makanan terntunya tidaklah hal yang selalu ada, sering kali terhambat sehingga memaksa masyarakat untuk menghemat makanan dan membeli bahan makanan di pasar gelap dengan harga yang lebih tinggi. Kejadian-kejadian ini digambarkan dalam komik seperti dalam Data 4.

(4)

$$
\begin{aligned}
& \text { すず：あの一一お砂糖はあ } \\
& \text { りますか } \\
& \text { 売り手：あるで、一斤（六百 } \mathrm{g} \text { ）二十円 } \\
& \text { すず：二十円！?はっ配給のろくじゅうばい。。。 } \\
& \text { 売り手：これでも安うしとろ今のういちに買わんとまだ高うなるで } \\
& \text { （この世界の片隅に 第 } 13 \text { 回, 2011, p. 160) }
\end{aligned}
$$

Suzu : : Ano...Osatou wa arimasuka

Urite : Arude, ikkin (ropyaku g) nijuuen

Suzu : Nijuuen!? Hah Haikyuu no Rokujuu bai...

Urite : Koredemo yasuushitoru imanouichi ni kawanto mada takaunarude

(Kono Sekai no Katasumi ni dai 13 kai, 2011, p. 160)

Suzu : Ano... Apakah ada gula?

Penjual : Ada tapi satu kin (600 g) harganya 20 yen

Suzu : 20 yen!? Hah!? Enam puluh kali lipat dari harga yang didistribusikan... 
Penjual : Ini Sudah murah jika kau cari di tempat lain. Lebih baik kau beli sekarang daripada nanti harganya akan lebih mahal

(Kono Sekai no Katasumi ni dai 13 kai, 2011, p. 160)

Pada Data 4 terlihat bahwa harga barang yang hendak di beli Suzu sangat mahal yakni sampai 60 kali lipat dari harga yang didistribusikan pemerintah. Sebelum penggalan percakapan pada data 4, Suzu secara tidak sengaja menjatuhkan pasokan gula di rumahnya sehingga Suzu harus membeli gula namun pasokan gula yang didistribusikan pemerintah habis dan tidak didistribusikan kembali dalam waktu dekat sehingga Suzu mengatakan hal itu kepada Ibu mertuanya lalu Ibu mertuanya memberikan uang dan menyuruh Suzu untuk membeli gula di pasar gelap. Setibanya di pasar gelap, Suzu mencari penjual pasokan makanan lalu menanyakan harga dari gula yang hendak dibeli Suzu. Pada saat mempertanyakan harga dari gula yang ingin dibeli oleh Suzu, Suzu juga menyinggung harga susu dan karamel yang semakin mahal.

Dari fakta sejarah, masa Perang Dunia II yang berakhir dengan ditandai dengan menyerahnya Jepang pada tanggal 2 September 1945, Amerika Serikat mengambil kependudukan Jepang hingga tahun 1952. Selama pada periode ini kebutuhan masyarakat akan bahan-bahan makanan semakin tinggi namun dibarengi dengan pasokan yang kurang sehingga pemerintah pendudukan Amerika Serikat mempertahankan sistem penjatahan yang dilakukan pemerintah Jepang selama perang berlangsung demi menjaga sumber daya yang ada (Cwiertka, 2013, p. 131). Namun walaupun begitu Amerika Serikat dan dan Jepang tidak dapat mengalokasikan pasokan makanan secara efisien sehingga mengakibatkan krisis kelaparan yang ekstrim pada masa itu (Solt, 2014, p. 6).

\section{b. Kerusakan Infrastruktur}

Kerusakan infrastruktur yang terjadi pada masa perang berupa rusaknya perumahan warga hingga fasilitas-fasilitas seperti transportasi berhenti beroperasi. Banyak dari masyarakat yang tinggal di rawan konflik lebih memilih meninggalkan tempat tinggal mereka demi menyelamatkan diri dan tinggal bersama keluarga lainnya yang berada di tempat yang lebih aman. Salah satu gambaran dalam komik yang menjelaskan kerusakan akibat bom yang terjadi saat peperangan pada tengah malam tanggal tanggal 1 Juli 1945 di Kure. Pada saat itu serangan dari Amerika Serikat terjadi pada tengah malam dengan diiringi suara berisik alarm tanda bahaya bergema di penjuru kota. Kure adalah kota yang dikelilingi oleh pegunungan, pada penyerangan ini bagian kota yang menjadi pusat penyerangan adalah perkotaan di bawah pegunungan sehingga orang-orang melarikan diri ke bagian pegunungan. Tempat tinggal Suzu berada di lereng pegunungan sehingga dampak dari penyerangan ini tidak terlalu parah seperti yang terjadi di bawah pegunungan. Salah satu keluarga Suzu yang tinggal di bawah pegunungan berhasil melarikan diri dari penyerangan ini menuju rumah Suzu dengan beberapa orang juga yang ikut melarikan ke arah lereng gunung. Kerusakan yang terjadi dijelaskan dengan data berikut. 


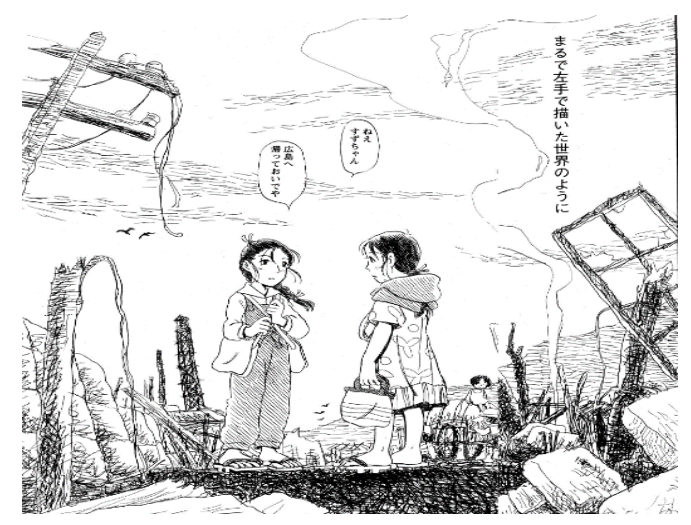

\section{Gambar 3. Kerusakan Infrastuktur pada wilayah rumah Suzu}

(Kono Sekai no Katasumi ni dai 35 kai, 2011, p. 127)

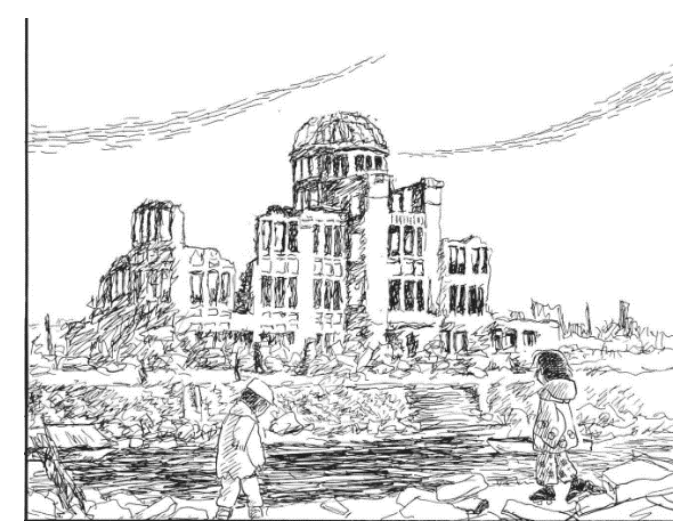

Gambar 4. Kerusakan Infrastruktur pada Hiroshima

(Kono Sekai no Katasumi ni dai 35 kai, 2011, p. 202)

Gambar 3 dan 4 merupakan penggambaran kerusakan infrastruktur yang terjadi di prefektur Hiroshima setelah bom atom dijatuhkan. Gambar 4 menunjukkan salah satu bangunan terkenal di Hiroshima yang masih bisa berdiri walaupun jarak serangan bom atom yang dijatuhkan di Hirsohima tidak terlalu jauh dari bangunan ini. Bangunan ini adalah salah satu Situs Warisan Dunia Unesco sejak tahun 1996. Monumen ini dikenal dengan Monumen Perdamaian atau sering disebut Genbaku Dome, ini merupakan simbol harapan umat manusia untuk perdamaian dunia dan pemusnahan senjata nuklir.

Pengeboman pada tanggal 6 Agustus 1945 pada waktu ditujukan untuk Jembatan Aioi, namun bom itu malah meledak langsung di atas Rumah Sakit Shima, yang sangat dekat dengan Genbaku Dome. Karena ledakan itu tidak terjadi di tanah namun di udara, bangunan itu mampu mempertahankan bentuknya (Ide, 2007, pp. 12-23). Tiang-tiang vertikal bangunan itu mampu menahan gaya ledakan yang hampir vertikal ke bawah, dan bagian-bagian dinding beton dan batu bata tetap utuh. Pusat ledakan terjadi 150 meter secara horizontal dan 600 meter secara vertikal dari Dome. Semua orang di dalam gedung terbunuh seketika. Daya tahan bangunan juga dapat dikaitkan dengan desain tahan gempa: memang, itu tahan gempa, sebelum dan sejak pemboman (Milam, 2010, pp. 32-35). 


\section{c. Kehilangan Keluarga}

Perang Dunia II merenggut begitu banyak korban meninggal dunia sehingga disebut sebagai konflik militer yang paling mematikan dalam sejarah. Diperkiraan terdapat sekitar 70 penduduk bumi binasa akibat peperangan tersebut. Jumlah ini sekitar 3\% dari populasi penduduk bumi pada tahun tersebut yang diperkirakan sebanyak 2,3 milliar penduduk. Sedangkan di Jepang sendiri sekitar 24,2\% pasukan militer Jepang dan 19,7\% pelaut Jepang meninggal dunia selama Perang Dunia II terjadi (Budge, 2016).

Banyak pula keluarga-keluarga yang kehilangan anggota keluarga mereka terutama anggota keluarga yang menjadi anggota militer dalam peperangan. Di dalam komik ini pemeran utama yakni Suzu mengalami hal tersebut. Suzu kehilangan seluruh anggota keluarganya secara perlahan dari kakak laki-lakinya yakni Yoichi yang menjadi seorang anggota militer angkatan laut yang dikabarkan meninggal dunia saat berperang, lalu keponakannya yakni Harumi yang meninggal akibat bom pada saat penyerangan di Kure hingga orang tuanya dan adik perempuannya yakni Sumi yang meninggal akibat bom atom yang dijatuhkan Amerika Serikat di Hiroshima. Kematian Yoichi digambarkan pada data gambar berikut.

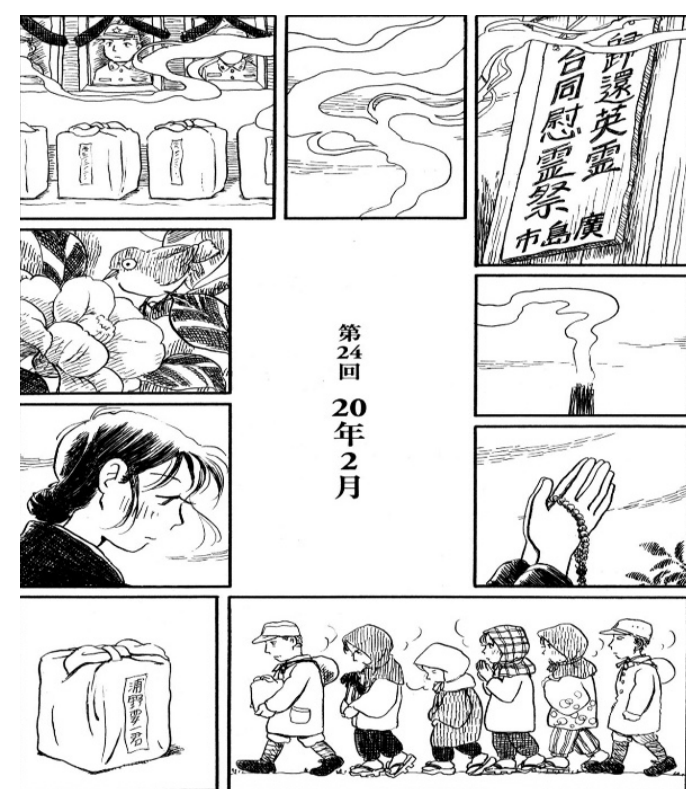

\section{Gambar 5. Kematian kakak laki-laki Suzu \\ (Kono Sekai no Katasumi ni dai 24 kai, 2011, p. 29)}

Gambar 5 menunjukkan anggota keluarga Suzu pergi untuk mendoakan dan mengambil abu Yoichi yang dikabarkan telah meninggal dunia dalam peperangan. Dalam gambar 5 terdapat papan yang tertulis "Kikan eirei, goudouireisai, hiroshimashi" 'Kembalinya roh-roh pahlawan perang, memorial untuk pahlawan perang, Kota Hiroshima'. Lalu terdapat bingkisan kotak yang dituliskan "Yoichi Urano" ini adalah nama dari kakak Suzu. Kotak bingkisan ini adalah kotak yang digunakan untuk menempatkan abu mayat dari Yoichi yang telah dikremasi.

Menurut dokumen-dokumen sejarah banyak menyebutkan perkiraan jumlah korban yang tewas pada masa Perang Dunia II. Menurut data dari Kementrian 
Kesehatan dan Kesejahteraan Jepang, korban tewas dari jepang selama Perang Dunia II sebanyak 3,1 juta korban tewas yang di antaranya 2,3 juta korban tewas dari tentara dan angkatan laut, sebanyak 500.000 warga sipil yang berada di Jepang, dan 300.000 warga sipil yang tinggal di luar Jepang (Ishikida, 2005, p. 30). Lalu menurut perhitungan yang lebih terperinci dari Werner Gruhl (2007, p. 144), korban tewas dari militer Jepang sebanyak 2.315.878 korban dari tahun 1941 sampai dengan tahun 1945. Sedangkan sebanyak 393.400 warga sipil Jepang menjadi korban pada Perang Dunia II (Budge, 2016). Data-data ini menunjukkan bahwa begitu banyak keluarga di Jepang khususnya di wilayah-wilayah peperangan yakni bagian selatan Jepang yang kehilangan keluarga mereka karena penyerangan-penyereangan yang dilakukan oleh Amerika Serikat pada kala itu.

\section{d. Sakit Akibat Bom Hiroshima}

Korban jiwa yang diakibatkan bom atom pada kala itu tidak hanya merenggut nyawa orang-orang pada saat itu juga, namun hingga saat ini masih banyak korban selamat yang menerima akibat dari bom atom ini yang dikarenakan oleh radiasi yang dihasilkan. Dilansir dari laman daring Hibakusha Stories (2020), orang-orang ini disebut sebagai Hibakusha (被爆者) atau jika diartikan berarti “orang yang terpapar bom" ( $h i$ 被 "terpapar" + baku 爆 "bom" + sha 者 "orang").

Di dalam komik Kono Sekai no Katasumi ni menunjukkan salah satu korban yakni ayah dari Suzu dan adik perempuannya yakni Sumi yang terpapar bom atom yang dijatuhkan Amerika Serikat di Hiroshima pada tanggal 6 Agustus 1945. Setelah bom terjadi, Sumi dan ayahnya mengkhawatirkan ibunya lalu pergi ke kota untuk mencari ibunya namun tak dapat ditemukkan. Karena pada saat itu Sumi dan ayahnya pergi ke kota yang telah diterjang bom atom, Sumi dan ayahnya terpapar radiasi yang dihasilkan bom atom tersebut yang mengakibatkan ayahnya tak lama setelah itu sakit-sakitan lalu meninggal dunia. Begitu pula dengan Sumi, Sumi juga terpapar radiasi dari bom atom tersebut yang ditunjukkan dalam gambar berikut.

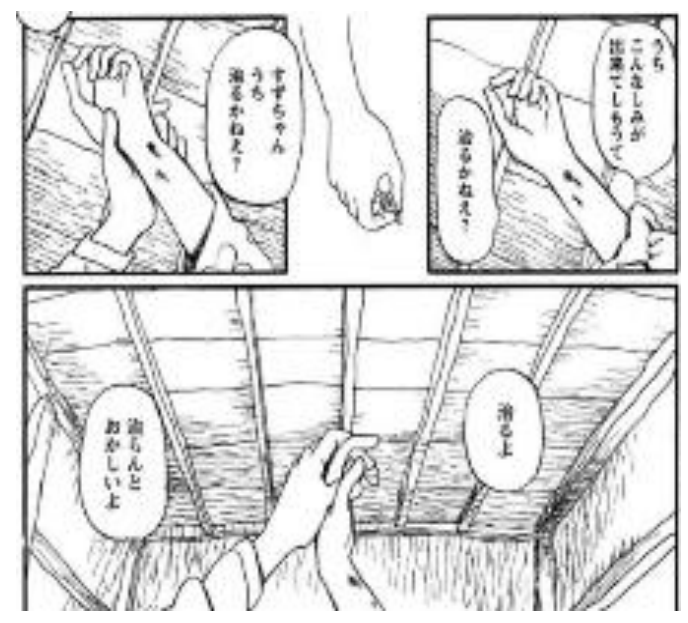

\section{Gambar 6. Sumi terpapar radiasi bom atom (Kono Sekai no Katasumi ni dai 44 kai, 2011, p. 197)}

Pada Gambar 6 ditunjukkan lengan Sumi yang terdapat luka memar yang dihasilkan oleh radiasi bom atom saat dia dan ayahnya pergi untuk mencari ibunya 
di kota setelah pengeboman terjadi. Luka-luka memar ini bukan hanya membuat bekas namun juga membuat badan Sumi melemah hingga harus berbaring dan tidak dapat beraktifitas seperti biasanya. Luka memar ini juga menyebar keseluruh badan Sumi.

Radiasi yang ditimbulkan oleh bom atom yang memusnahkan Kota Hiroshima pada saat itu mengakibatkan banyak orang meninggal dunia akibat efek dari radiasi tersebut. Sumi secara langsung tidak terpapar dengan ledakan bom atom pada saat itu sehingga ia hanya mengalami gejala-gejala radiasi kulit atau yang disebut dengan Cutaneous radiation syndrome (CSR). Dilansir dari laman daring Centers for Disease Control and Prevention (2018), Sindrom ini mengacu pada gejala kulit dari paparan radiasi. Dalam beberapa jam setelah radiasi akan muncul kemerahan sementara di kulit dan sering kali terasa gatal dapat terjadi. Kemudia fase laten dapat terjadi dan berlangsung dari beberapa hari hingga beberapa minggu, ketika kemerahan di kulit yang semakin intens yang diikuti dengan kulit melepuh.

Dilansir dari laman daring The Japan News (2019), Pemerintah telah mengakui sekitar 650.000 orang dinyatakan sebagai hibakusha dan data pada tanggal 31 Maret 2019 sekitar 145.844 orang dinyatakan masih hidup. Dari semua hibakusha ini, pemerintah menyatakan hanya sekitar $1 \%$ dari mereka yang memiliki penyakit dari radiasi. Laporan Miyazaki (2019) dalam Asahi Shimbun data yang diterbitkan dan diperbaharui setiap tahunnya pada acara peringatan pemboman, pada Agustus 2019, telah tercatat di tugu memorial sebanyak lebih dari 500.000 hibakusha meninggal dunia yakni sebanyak 319,186 di Hiroshima dan sisanya di Nagasaki.

\section{PENUTUP}

Hasil penelitian yaitu ditemukan beberapa peristiwa-peristiwa sejarah yang digambarkan dalam komik Kono Sekai no Katasumi ni karya Fumiyo Kouno. Peristiwa sejarah yang digambarkan diantaranya program tonarigumi yang dibentuk oleh pemerintah Jepang untuk menunjang keberhasilan dalam perang yang sedang berlangsung pada masa itu. Digambarkan pula salah satu kebijakan pemerintah Jepang pada masa perang yakni tatemono sokai, kebijakan ini mengacu pada penataan bangunan-bangunan di seluruh Jepang guna menghindari kebarakan yang semakin meluas pada saat serangan bom terjadi. Terdapat juga gambaran sejarah pada saat serangan-serangan udara musuh di wilayah Kure hingga merusak fasilitas Pangkalan Angakatan Laut Hiro yang berada di Kure serta terjadinya serangan bom nuklir pertama dan terbesar sepanjang sejarah manusia yang berada di Hiroshima.

Dapat disimpulkan dalam penelitain ini yaitu terdapat dampak ekonomi dan sosial. Pada dampak ekonomi terjadi keruntuhan ekonomi di Jepang sehingga untuk mendapatkan bahan-bahan makanan pada masa itu sangatlah sulit dan berat, ditambah dengan penduduk yang kehilangan tempat tinggal serta kerusakankerusakan infrastruktur. Dalam segi sosial yaitu banyaknya korban jiwa yang harus meninggal dunia serta penyakit yang meninggalkan luka fisik maupun mental pada korban-korban yang masih hidup hingga komik ini diciptakan

\section{DAFTAR PUSTAKA}

Abrams, M. H. (1999). A Glosary of Literary Terms. Amerika: Thomson Learning. Akira, K. (1991). Tōkyō no toshi keikaku. Tokyo: Iwanami Shinsho.

Budge, K. G. (2016). The Pacific War Online Encyclopedia: Casualities. Retrieved from http://pwencycl.kgbudge.com/C/a/Casualties.htm 
Carter, K. C., \& Mueller, R. (1991). U.S. Army Air Forces in World War II: Combat Chronology. Washington, D.C.: Center Air Force History.

Craven, W., \& Cate, J. (1953). The Pacific: Matterhorn to Nagasaki. Dalam the Army Air Forces in World War II Volume V. Chicago: The University of Chicago Press.

Cwiertka, K. J. (2013). Food and War in Mid-Twentieth Century East Asia. Farnham, United Kingdom: Ashgate Publishing Company.

Gruhl, W. (2007). Imperial Japan's World War Two: 1931-1945. New Brunswick: Transaction Publishers.

Hayakawa, Y. (2015). Memories of War 002: Koji Hosokawa. Morrisville: Lulu Press Inc.

Ide, K. (2007). A Symbol of Peace and Peace Education: The Genbaku Dome in Hiroshima. Aesthetic Education, 41(4), 12-23. doi: 10.1353/jae.2007.0036

Ishikida, M. (2005). Toward Peace: War Resposibility, Postwar, Compensation, and Peace Movements and Education in Japan. New York: iUniverse Inc.

Johnson, W. (2006). The Pacific Campaign in World War II: From Pearl Harbor to Guadalcanal. Abingdon, Oxon: Routledge.

Kawaguchi, T. (2011). The Change of Purpose of Execution and Passage in The Building Evacuation During World War II. Architecture and Planning, 77(666), 1509-1515. doi: 10.3130/aija.76.1509

Malino, C. D. (2014). Fakta Sejarah Perang Dunia II Dalam Novel Mawar Jepang Karya Rei Kimura, University of Brawijaya, Indonesia.

Milam, M. C. (2010). Hiroshima and Nagasaki. Humanist. New York: American Humanist Association and the American Ethical Union.

Miyazaki, S. (2019). Hiroshima urges Japan to ratify anti-nuke treaty at $74^{\text {th }}$ ceremony. Retrieved from http://www.asahi.com/ajw/articles/AJ201908060036.html

Mizukawa, K. (2020). Striving to fill voids in Hiroshima 75 years after the atomic bombingDispersed materials, Part 8: Significance of original work. Retrieved from http://www.hiroshimapeacemedia.jp/?p=98436\&query=tatemono+sokai

Pekkanen, R. (2006). Japan's Dual Civil Society. Members without advocates. Standford, California: Stanford University Press.

Pekkanen, R. (2009). Local Organizations and Urban Governance in East and Southeast Asia: Straddling State and Society. New York: Routledge.

Ratna, N. J. (2007). Sastra dan Culture Studies: Representasi Fiksidan Fakta. Yogyakarta: Pustaka Pelajar.

Romei, S. (2017). 6 years after the Fukushima disaster, its victims are still suffering. Retrieved from https://www.almendron.com/tribuna/6-years-after-thefukushima-disaster-its-victims-are-still-suffering/

Solt, G. (2014). The Untold History of Ramen. Berkeley, California: University of California Press.

The Japan News. (2019). World free of nuclear weapons urged at Hiroshima ceremony. Retrieved from https://the-japan-news.com/news/article/0005922619

Thomas, G., \& Morgan-Witts, M. (1977). Ruin from the Air. London: Hamilton.

Tibbets, P. (2014). 509 $9^{\text {th }}$ Timeline: Inception to Hiroshima. Retrieved from https://www.atomicheritage.org/history/509th-composite-group

William, M. (2003). New Historicism and Literary Studies. Soka Kyouiku Kenkyuu, 27, 115-144. 